\title{
活断層で起きた歴史地震の大きさ
}

\author{
国土地理院地理地殼活動研究センター* 小田切聡子 \\ 東京大学地震研究所** 島 崎 邦 彦
}

\section{Size of the Historical Earthquake Which Occurred on an Active Fault in Japan}

\author{
Satoko OdAGIRI \\ Crustal Dynamics Laboratory, Geography and Crustal Dynamics Research Center, \\ Geographical Survey Institute, Kitasato 1, Tsukuba, Ibaraki 305-0811, Japan
}

\author{
Kunihiko Shimazaki \\ Earthquake Research Institute, University of Tokyo, Yayoi 1-1-1, \\ Bunkyo-ku, Tokyo 113-0032, Japan
}

(Received May 18, 1999; Accepted March 31, 2000)

\begin{abstract}
For a prediction of magnitude of future earthquake on an active fault, it is important to estimate what portion of the fault will move in a single earthquake. Using a data set of 36 historical inland earthquakes which can be correlated to previously mapped active faults, we estimate the ratio of rupture length of historical events to the length of "seismogenic faults" proposed by MATSUDA (1990) (Matsuda model). We found that the ratio is distributed from $1 / 4$ to 1 , indicating that there are a significant number of events in which only portions of "seismogenic faults" of MATSUDA (1990) moved, although these "seismogenic faults" were thought to rupture in a single earthquake. Among thirty Matsuda model faults examined in this study, fifteen can be divided into segmented faults according to Кимамото (1998) who proposed each segmented fault ruptures in a single earthquake (Kumamoto model). The ratio of rupture length to the length of Matsuda model fault for those fifteen faults is also distributed from $1 / 4$ to 1 and this cannot be explained by Kumamoto model. We propose a new fault model which includes Matsuda model, Kumamoto model, and groups of faults composed of neighboring fault segments. We assumed equal probability for earthquake occurrence on all the modeled faults. A numerical simulation for reproducing nineteen historical earthquakes correlated with the fifteen Matsuda model faults which are divided into segments by Кимамото (1998), shows that our proposed model best explains the observed distribution of fault length ratio of historical earthquake data.
\end{abstract}

Key words: Active faults, Historical earthquakes, Seismogenic faults, Segmentation, Earthquake magnitude.

§1.はじめに

日本列島には活断首が無数に刻まれており，陸域に震 源をもつ大地震の多くは活断層の活動によって発生して いる.これらの地震は, プレート境界で起こる地震に比 べれば繰り返し間隔も長く, 規模も小さいが, 人々が生 活する土地の直下で発生するため被害は甚大であり, 我々は 1995 年兵庫県南部地震でそれを目の当たりにし
た．地震災害を軽減させるためには，地震の発生時期と 規模の長期予測に基づく対策が重要となる. 発生時期の 予測については, 最近確率論に基づく手法が提案されて いる [地震調查研究推進本部地震調査委員会長期評価部 会 (1999)]。しかし，地震規模の予測に関する研究はあ まり進んでいない.

陸域で発生する大地震はしばしば地表地震断層を伴
** テ113-0032 東京都文京区弥生 1-1-1 
う. 1998 年岩手県内陸北部の地震 $(M 6.1)$ では地表地震 断層が現れたが, 日本において, 地表地震断層が現れる 地震の規模は一般に地震モーメント $7.5 \times 10^{25}$ dyne・ $\mathrm{cm}$ 以上と考元られており [SHIMAZAKI (1986)], 気象庁 マグニチュードでは $M 6.8$ 以上と求められる [武村 (1998)]. 既知の陸域活断首は過去に生じた地表地震断 層の痕跡であり，それらの長さは過去の大地震の規模を 推定する上で 1 つの指標となる. しかし，これまでの活 断層調査により，1つの活断層は，全体が一度に動くこ ともあれば，一部分しか動かないこともあり，またある 場合には，周辺の活断層と同時に動くこともあるなど, 地震ごとに動く活断層の長さは必ずしも一定ではない， 活動する活断層の長さが異なれば, 予測される地震規模 あ変わるので, 1 回の大地震で活断層がどのように動く かということは, 地震規模の予測において最も重要な問 題である. 本研究では日本列島の陸域活断層を全体的, 統計学的に扱い, 大地震発生時にまこまって活動する活 断層群（あるいは活断層の区間）と地震の規模の関係に ついて議論を進めていく.

\section{§2. 大地震発生時の活動単位となる断層設定}

1 つの活断層のどの範囲が動くか（セグメンテーショ ン), あるいはいくつの活断層が同時に動くか（グルーピ ング)，を把握することが，その地域で生じる大地震の規 模を予測する上で必要である．松田 (1990) はこのよう な観点から，1回の地震で同時に動く可能性のある活断 層（群）を「起震断層」と呼び, 次のような基準で設定 した。（1） $5 \mathrm{~km}$ 以内に他の活断層のない孤立した長さ $10 \mathrm{~km}$ 以上の活断層, (2) 走向方向に $5 \mathrm{~km}$ 以内の分布 間隙をむって，ほぼ一線に並ぶほぼ同じ走向の複数の断 層, (3) $5 \mathrm{~km}$ 以内の相互間隔をむって並走する幅 $5 \mathrm{~km}$ 以内の断層群，(4) その断層線の中点の位置が主断層か ら $5 \mathrm{~km}$ 以上はなれている走向を異にする付随断層ある いは分岐断層.

松田 (1990) は，上記の基準で再編成された起震断層 について, 特定断層（そこで発生しうる最大の地震マグ ニチュードが, 付近で発生した歷史地震と比較して例外 的に大きくなる断層）に指定されたもの以外は，おおむ ね 1 つの大地震でその全部分が活動し, その長さに応じ た規模の地震を起こす（地震エネルギーの一括放出型） と考えても大きな誤りではないとしている（特定断層は 地震エネルギーの分割放出型としている).

これに対して，これまでのトレンチ調查などから，松 田 (1990) の特定断層以外の起震断層す全体が一度に動 く場合と，一部分しか活動しない場合のあることが明ら かになっている [隈元 (1998)]．それを踏まえて隈元
(1998) は, 活断層研究 (1991) の活断層分布図をあとに, 松田 (1990) の基準を用いて日本全国の活断層をグルー プ化した（一括放出モデル）。さらに長さ $30 \mathrm{~km}$ 以上に グループ化された活断層群について, トレンチ調查結果 および断層ステップや断層ジョグなどの活断層分布の不 連続に基づき, 長さ $15 〜 20 \mathrm{~km}$ になるようにいくつか のセグメントに分割した（分割放出モデル）。本研究で は, 松田(1990)の起震断層を「松田モデル」, 隈元 (1998) の分割放出モデルを「隈元モデル」と呼ぶ.

以上のように大地震発生時の活動単位となる断層設定 として, 松田モデルと隈元モデルが提唱されているが, 歷史地震における活断層の動きが，全国的に見て松田モ デルと隈元モデルのどちらの傾向をあつのかは把握され ていない，そこで本研究では，(1) 歴史地震デー夕調査に より, 歴史地震之松田 (1990) の起震断層を対応付け, 歴 史地震の推定規模と, 松田モデルから計算される地震の 規模を比較することにより，松田モデルの断層設定の妥 当性を検証する. (2) 隈元モデルを用いて, シミュレー ションにより歴史地震の規模と発生頻度の関係を求め,

(1) の歴史地震デー夕調査結果と比較することにより隈 元モデルの断層設定の妥当性を検証し，より現実的な断 層設定を考察する. (3) (1), (2) の結果を踏まえ，日本陸域 活断層で発生する大地震の規模の特徴について議論す る.

大地震と活断層の活動に関する研究は, San Andreas 断首などにおいて数多く進められている. SCHWARTZ and COPPERSMITH (1984) は, 地形・地質学的調查およ び地震データの検討から, San Andreas 断層等の 1 つ のセグメントに打いて, 発生する大地震の規模は一定 で，ずれの量は断層に沿って変化するが，ある点（ある いは区間）においては一定であるという証拠を得て，固 有地震モデルを提唱した. SIEH et al. (1989) や ARROWSMITH et al. (1997) は，詳細なトレンチ調查結果などを あとに，地震サイクルごとに破壊される領域（断層の範 囲）が異なることを指摘している. Working Group on California Earthquake Probabilities (1995) は, San Andreas 断層の各セグメントの地震デー夕と活動パ ターンを調べ，複数のセグメントが同時に動くことを考 慮して地震発生確率を求めた。本研究では, これらの研 究結果を参考にしつつ, 日本列島の陸域活断層の振る舞 いについて検討を進める．ただし，San Andreas 断層は プレート境界の断層であるのに対し，本研究で扱う陸域 活断層はプレート内の断層であり，その挙動は異なる可 能性がある。 


\section{§3. 歴史地震デー夕調査}

\section{1 調查手法}

まず歴史地震に関する文献から陸域に震源をもつ地震 を抽出し，活断層の活動履歴に関する既存の文献・資料 を用い，歴史地震と松田 (1990) の起震断層の対応付け を行う。次に，対応付けられた歷史地震の推定規模（主 に宇佐美 (1996) によった）をもとに，地震発生時に動い た断層の長さを推定する．この時，佐藤・他 (1989) の 「日本の地震断層パラメター・ハンドブック」に記載さ れている地震の場合は, 求められたパラメ一タの 1 つで ある震源断層の長さの值を引用し, それ以外の地震につ いては, 松田 (1975) のマグニチュード $M$ と断層の長さ
$L(\mathrm{~km})$ の関係式に, 宇佐美 (1996) による歴史地震のマ グニチュード值を代入し断層の長さを計算した.

$$
\log L=0.6 M-2.9
$$

この場合, 断層の長さ $L$ は地表地震断層の長さとされ ているが，式を導く際に使用されたデー夕には震源断層 の長さが含まれている．武村 (1998) は, $M 6.8$ 以上の地 震については (1) 式から算出される断層の長さを震源断 層の長さと考えてよいとしており，よって以下であ震源 断層の長さとして取り扱う.

最後に, 起震断層の長さに対する地震時に動いた断層 の長さの割合を計算し，その割合別地震発生頻度分布を 求めた，集計の際には，起震断層の長さに対する地震時

Table 1. Correlation of a "seismogenic fault" of Matsuda (1990) with historical earthquakes.

\begin{tabular}{|c|c|c|c|c|c|c|}
\hline No. & Matsuda (1990)'s Seismogenic Faults & $\mathrm{Eq}(\mathrm{M})$ & Rank & Lf(km) & $\mathrm{Lr}(\mathrm{km})$ & Ratio (Lr/Lf) \\
\hline 1 & Tsugaru_sanchi_seien & $1766(7.25)$ & c & 30 & 28 & 0.93 \\
\hline 2 & Noshiro ${ }^{1)}$ & $1694(7.00)$ & C & 24 & 20 & 0.83 \\
\hline 3 & Yokote_bonchi_toen & $1896(7.20)$ & a & 54 & 26 & 0.48 \\
\hline 4 & Gokurakuji_Nanamagari_toge & $1914(7.10)$ & d & 18 & 23 & 1.28 \\
\hline \multirow[t]{2}{*}{5} & Shonai_heiya_toen & $850(7.00)$ & b & 22 & 20 & 0.91 \\
\hline & & $1894(7.00)$ & a & 22 & 20 & 0.91 \\
\hline 6 & Aizu_bonchi_seien & $1611(6.90)$ & a & 35 & 17 & 0.49 \\
\hline 7 & Nagaoka_nisi & $1828(6.90)$ & c & 25 & 17 & 0.68 \\
\hline 8 & Sekiya & $1683(7.00)$ & c & 40 & 20 & 0.50 \\
\hline 9 & Fukaya $^{2)}$ & $818(7.50)$ & c & 50 & 40 & 0.80 \\
\hline 10 & Hirai_Kushibiki & $1931(6.90)$ & c & 20 & $20^{*}$ & 1.00 \\
\hline 11 & Arakawa & $1855(6.90)$ & $d$ & 20 & 17 & 0.85 \\
\hline 12 & Isehara & $878(7.40)$ & b & 20 & 35 & 1.75 \\
\hline \multirow[t]{2}{*}{13} & Tanna & $841(7.00)$ & a & 30 & 20 & 0.67 \\
\hline & & $1930(7.30)$ & a & 30 & $24^{*}$ & 0.80 \\
\hline 14 & Shinanogawa & $1847(7.40)$ & a & 60 & 35 & 0.58 \\
\hline 15 & Itoshizusen_chubu & $762(7.00)$ & c & 112 & 20 & 0.18 \\
\hline 16 & Atotsugawa & $1858(7.05)$ & a & 61 & 21 & 0.34 \\
\hline 17 & Atera & $1586(7.80)$ & a & 62 & 60 & 0.97 \\
\hline \multirow[t]{2}{*}{18} & MTL_Akaishi_nishi & $715(7.00)$ & c & 52 & 20 & 0.38 \\
\hline & & $715(6.75)$ & c & 52 & 14 & 0.27 \\
\hline 19 & Fukui_heiya_toen & $1948(7.10)$ & c & 30 & $30^{*}$ & 1.00 \\
\hline \multirow[t]{2}{*}{20} & Neodani & $745(7.90)$ & b & 67 & 69 & 1.03 \\
\hline & & $1891(8.00)$ & a & 67 & $85^{*}$ & 1.27 \\
\hline 21 & Yanagase & $1909(6.80)$ & d & 56 & 15 & 0.27 \\
\hline 22 & Kizugawa & $1854(7.25)$ & c & 30 & 28 & 0.93 \\
\hline 23 & Gomura $^{3)}$ & $1927(7.30)$ & a & 13 & $35^{*}$ & 2.69 \\
\hline \multirow[t]{2}{*}{24} & Hanaore & $1185(7.40)$ & c & 54 & 35 & 0.65 \\
\hline & & $1662(7.40)$ & b & 54 & 35 & 0.65 \\
\hline \multirow[t]{2}{*}{25} & Arima_Takatsuki & $827(6.75)$ & c & 53 & 14 & 0.26 \\
\hline & & $1596(7.00)$ & a & 53 & 20 & 0.38 \\
\hline 26 & Rokko-Awaji ${ }^{4)}$ & $1995(7.20)$ & a & 62 & $45^{* *}$ & 0.73 \\
\hline 27 & Ikoma & $734(7.00)$ & $b$ & 30 & 20 & 0.67 \\
\hline 28 & Uemachi $^{5)}$ & $1510(6.75)$ & c & 43 & 14 & 0.33 \\
\hline 29 & Yamasaki & $868(7.00)$ & b & 55 & 20 & 0.36 \\
\hline 30 & Mino & $679(7.00)$ & a & 20 & 20 & 1.00 \\
\hline
\end{tabular}

All the "seismogenic faults" are from Matsuda (1990), except for 1) and 3) from ResEARCH GROUP for Active Faults of Japan (1991), 2) from Satake et al. (1997), 4) from Matsuda (1995), and 5) from Sugryama (1997). The year of historical earthquake (Eq) and magnitude $(M)$ are taken from UsAmi (1996). The rank shows the reliability of the correlation in alphabetical order; the highest reliability is shown by rank a and the lowest by rank d. The length of Matsuda model fault is shown by $L f$ and the estimated rupture length is by $L r$. The rupture length listed in SAto et al. (1989) is shown by an asterisk and that taken from НАsнiмото et al. (1995) is by double asterisks. The other values of rupture length are estimated from the earthquake magnitude on the basis of MATSUDA (1975)'s empirical formula. The ratio of $L r$ to $L f$ is shown in the last column. 
に動いた断層の長さの割合を $1 / 4$ 単位の階級（中央值が 1/4の倍数）に分類した.

\section{2 調查結果と松田モデルの検討}

本研究では 36 の歷史地震に対して, 松田 (1990) の起 震断層 30 本が対応付けられた [Table 1, 対応付けに関 する詳細は小田切・島崎 (2000) を参照]. ただし, 対応 付けに適した松田 (1990) の起震断首がないため, 別の 文献から新たに設定した起震断層を含む（その場合は Table 1 の説明に出典を記載). その際, 対応付けの確実 性を示す 4 つのランク（確実性の大きい順に $\mathrm{a} \sim \mathrm{d}$ ）を設 定した。

a: 地表地震断層の出現や活断層の最新活動時期が一 定期間に限定できる地質年代資料により, 対応付 けが確実と考えられるすの.

b: トレンチ調査などにより活断層の最新活動時期の 推定に有用な地質年代資料がえられており, 対応 付けがほぼ確実と考えられるもの.

c: 地質年代資料に欠けるが, 歴史地震と活断層の対 応付けを推定した文献・資料が存在するもの.

$\mathrm{d}$ : 地質年代資料や対応付けを推定した文献・資料は ないが, 地震規模, 震央位置, 被害状況などから可 能性のあるもの. あるいは, 文献・資料はあるが, その情報に対する信頼性に問題があるもの.

Table 1 には, 起震断層名, 歴史地震の年代とマグニ

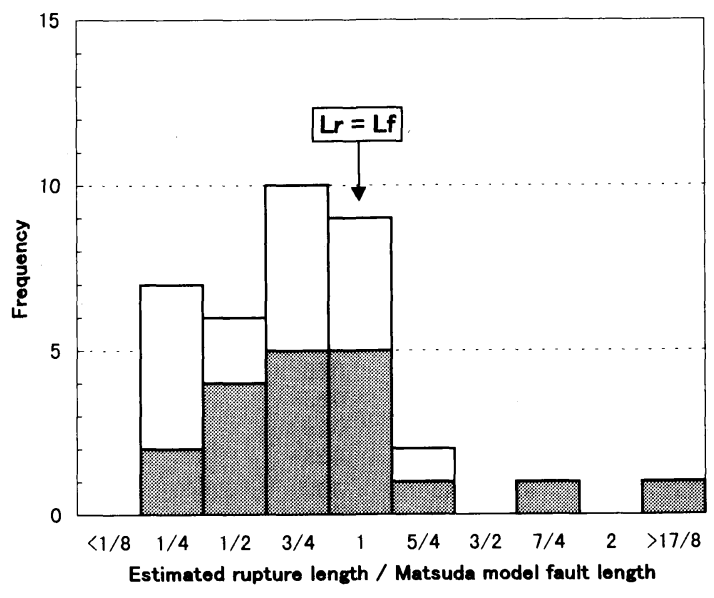

Fig. 1. Histogram of ratios of rupture lengths during historical earthquakes to MatsudA (1990)'s "seismogenic faults" (Matsuda model) listed in Table 1. Shading shows data with reliability ranks $a$ and $b$ in Table 1. If all fault segments within a Matsuda model fault rupture simultaneously in a single event, the rupture length $(L r)$ should be equal to the length of Matsuda model fault $(L f)$.
チュード, 対応付けのランク, 起震断層の長さ $(L f)$, 地 震時に動いたと推定される断層の長さ $(L r)$, 起震断層長 に対する地震時に動いた断層の長さの割合 $(L r / L f)$ が 記載されている. Table 1 に基づいて, 起震断層長に対 する地震時に動いた断層の長さの割合別地震発生頻度分 布図 (Fig. 1) を作成した. Fig. 1 より, 対応付けられた 全歷史地震数 36 のうち約 $89 \%$ にあたる 32 の歴史地震 が, 割合が 1/4〜1 の間に分布することがわかった. 対 応付けの確実性ランク上位の $2 つ(a, b)$ の数を見ても, 割合が $1 / 4$ の地震はやや少ないものの, 類似した傾向を 示すことから, 過去の大地震において, 松田 (1990) の起 震断層はその全長に対して 1/4 1 の部分が動くという 傾向があると言える.

Fig. 1 には割合が $5 / 4$ を超える地震が 2 つある.この うちの 1 つは 1927 年北丹後地震で, 当地震で活動した のは郷村断層と山田断層である. 松田 (1990) は山田断 層のみ起震断層と設定しているが, 推定された震源断層 [MATSU'URA (1977)] の走向は主として郷村断層の走向 と一致することから, 本研究では郷村断層を対応付け た. 郷村断層の長さは活断層研究会 (1991) から引用し たが，それは陸上で確認できる部分だけの長さである.

一方, 推定された震源断層は陸から北の沖合まで延びて おり，そのために割合が 1 を大きく超えたと考えられ る. あう 1 つは 878 年の地震で, 当地震で活動した松田 (1990) の起震断首は伊勢原断層之推定されている [松 田・他 (1988)]. 伊勢原断層は特定断層に指定されてい ないことから，この対応付けが確実であるならば, 松田 (1990) の起震断層の設定基準は, 1 つの大地震でまと まって活動する活断層群として適さない場合がある可能 性を示唆している。 しかし, 松田・他 (1988)の 878 年 地震と伊勢原断層の対応付けの根拠に対する異論あある ことから [小山(1999)], 対応付けに関して問題が残さ れているかむしれない. また, 松田 (1990)の起震断層 は, 活断層研究会 (1980) の活断層分布図を用いている ため, その後確認された活断層が含まれていないこと, 海底活断層が十分確認されていないため，1つの起震断 層にグルーピングされるべき活断層が別々の起震断層に 編成されている場合があること, などを考慮すると, 起 震断層の編成が不適切である可能性むある.

歴史地震デー夕調查結果において, 割合が 1 であるこ とは全体が一度に動くことを示し，1 未満であることは 部分的に動くことを意味する.したがって Fig. 1 より, 松田 (1990) の起震断層は, 一括放出型だけでなく, 分割 放出型も多いことがわかり, 隈元 (1998) の主張が裏付 けられた。

あし松田 (1990)の起震断層の編成が適切であれば, 
割合が 1 を超える地震は存在しないと考えられる. しか し，先に述べたような対応付けや起震断層の編成の問題 がない場合でも, 割合が確実に 1 を超える地震が存在す る. それは 1891 年濃尾地震で, その震源断層の長さは 根尾谷断層帯の長さより約 $30 \%$ 長い. しかし, 割合が 1 を超えると地震数は明らかに急減することから, 松田 (1990) の起震断層の設定基準は, 最大規模の地震発生時 における活動単位となる断層設定として妥当であると考 えられる.この結果より, 以下松田 (1990) の起震断層 は, 基本的に最大規模の地震発生時における活断層の活 動単位として正しくグルーピングされているものとして 扱う.

\section{§ 4. 断層設定より推定される歴史地震の規模と発生} 頻度

4.1 隈元モデルを用いた歴史地震のシミュレーショ ン

§3 の歴史地震デー夕調查より，松田 (1990) の起震断 層は,つねに全体が一度に動くわけではなく, 部分的に も動くことがわかり, 部分的に動く場合, 松田モデルは 1 つの大地震の活動単位としての断層設定としては適さ ない. それに対して隈元モデルは, 松田モデルのうち分 割放出型と考えられる起震断層について，1つの大地震 における活動単位となる断層区間として, いくつかのセ グメントを設定している. Fig. 1 について, 隈元 (1998) で断層セグメントに分割されなかった起震断層と複数の 断層セグメントに分割された起震断層のグラフに分けた (Fig. 2).

断層セグメントに分割されなかった起震断層のグラフ [Fig. 2(a)] は, 割合が 1 および $3 / 4$ の地震が同程度に分 布する. 割合が $3 / 4$ の地震の存在は, 歴史地震のマグニ チュードの過小評価が原因である可能性があり, 歴史地 震のマグニチュードが正しく評価されていれば, 割合が 1 の地震しか発生せず，つねに全体が一度に割れると考 えることができる.しかし，断層セグメントに分割され ない起震断層の長さは 20 $30 \mathrm{~km}$ 程度であり, 本研究 で扱う歴史地震は $M 6.8$ 以上のため, 割合が $1 / 2$ や $1 / 4$ である地震が存在してもグラフには表れない. 断層セグ メントに分割されない起震断層においても, 複数の断層 セグメントに分割される起震断層で起こる地震のような 分布 [Fig. 2(b)] をする可能性がある. しかし現在のデー タからはこれ以上のことは言えない.

複数の断層セグメントに分割された起震断層のグラフ [Fig. 2(b)] は, 割合が 1/4〜1 の範囲で地震が分布する. 隈元モデルでは, 分割された断層セグメントは独立して 活動するとされているため, 割合が $3 / 4$ や 1 の地震が
存在する Fig. 2 (b) の結果は, 隈元モデルと合わないよ うに見える. 歴史地震のマグニチュードの過小評価によ り, 割合が $3 / 4$ である地震が発生している可能性あある が，デー夕数が少ないためこれ以上議論することはむず かしい.

本研究では, 隈元モデルが 1 つの大地震における活動 単位となる断層設定としてより現実的であるかどうかを 検証するため, 隈元モデルの断層セグメントのいずれか が過去の歴史地震で動いたと仮定し, 隈元モデルから推 定される地震規模別発生頻度分布を数值シミュレーショ ンにより求め, $\$ 3$ の歴史地震デー夕調査結果と比較し た. シミュレーションには, 隈元 (1998) で複数のセグメ
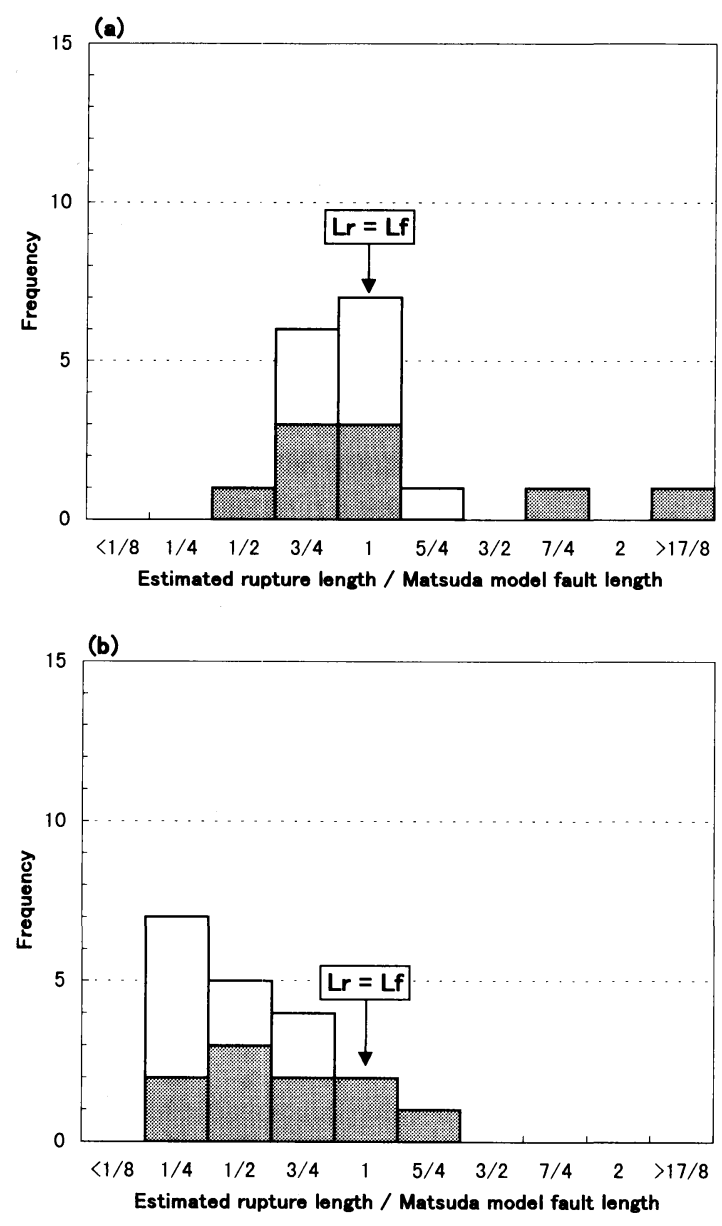

Fig. 2. Histogram of ratios of rupture lengths during historical earthquakes to Matsuda model faults listed in Table 1. (a) Matsuda model faults which cannot be divided. (b) Matsuda model faults which Кимамото (1998) divided into more than two segmented faults. See captions of Fig. 1. 
ントに分割された 15 本の起震断層に属する断層セグメ ント (Table 2) と，この起震断層に対応付けられた 19 の歴史地震を用いた.

過去の歴史地震において, 隈元 (1998) のどの断層セ グメントが活動したかは明確にわからないことから，歴 史地震発生時に活動した断層セグメントを数值シミュ レーションにより推定した. 具体的には, 起震断層ごと に属する断層セグメントに通し番号を振り, 対応付けら れた歴史地震の数だけ乱数を発生させる. 発生させる乱 数は 1 から各起震断層に属する断層セグメント数まで の整数值で, 乱数に対応する断層セグメントが歴史地震 発生時に活動したと考える.このようにして抽出された 断層セグメントについて，それぞれが属する松田 (1990) の起震断層の長さ $(L f)$ に対する断層セグメントの長さ $(L r)$ の割合 $(L r / L f)$ を計算し, §3 の歴史地震デー夕調 查と同様に割合 $(L r / L f)$ 別地震発生頻度分布を求めた。 以上の操作を 1 回の試行として 1000 回の試行を行い, $L r / L f$ の各区間ごとの地震発生頻度について平均と信頼 率 95\%の区間を求めた.

\section{2 シミュレーション結果と隈元モデルの検討}

隈元モデル（Table 2 の断層セグメント）を用い た場合のシミュレーション結果を Fig. 3 に示す. (a) は Table 2 のすべての断層セグメントが 1 回ずつ活動した 場合の割合 $(L r / L f)$ 別地震発生頻度分布, (b) は 4.1 の シミュレーションにより抽出された断層セグメントが活
動した場合の割合 $(L r / L f)$ 別地震発生頻度分布である.

シミュレーションの結果 [Fig. 3(b)] 歴史地震デー夕 調查結果と比較すると, 割合が $1 / 4$ と $1 / 2$ の地震の発 生頻度はよく対応しているが, 割合が $3 / 4$ や 1 の地震 は全く発生しない. Table 2 よりわかるように, 隈元モ デルはあともと起震断層の長さに対する断層セグメント の長さの割合が $3 / 4$ になる断層セグメントが存在しな い. また，隈元モデルの定義により，割合が 1 になる断 層セグメントは含まれない. したがって必然的に割合が 3/4 1 である地震は発生せず, 歴史地震デー夕調査結 果 [Fig. 2(b)] をうまく説明することができない．隈元 (1998) は, 一括放出モデルとしてグルーピングした活断 層群 [松田 (1990) の起震断層に相当］のうち, 全体の長 さが $30 \mathrm{~km}$ 以上のあのを, 複数のセグメントに分割し たが, 分割された個々のセグメントは独立してセグメン 卜全体が一度に動くと考えているので，各断層セグメン 卜は本質的には松田 (1990) の起震断層と同じであり, 歴史地震デー夕調査結果とうまく対応しないと考えられ る.

\section{3 連動セグメントモデル}

4.2 より隈元モデルも 33 の歴史地震デー夕調査結果を 十分説明することができない，そこで，隣接するセグメ ントはしばしば同時に活動しているという事実を考慮 し，隈元 (1998)の隣接する断層セグメントの可能な組 合せすべてを, 1 回の大地震の活動単位となる断層区間

Table 2. Segmented faults of Кимамото (1998).

\begin{tabular}{|c|c|c|c|c|c|c|c|c|c|c|c|}
\hline \multirow{2}{*}{ No. } & \multirow{2}{*}{$\begin{array}{l}\text { Kumamoto (1998)'s Segmented faults } \\
\text { Yokote_bonchi_toen }\end{array}$} & \multicolumn{4}{|c|}{ Lf(km) Lr(km) Ratio } & \multirow{2}{*}{ No. } & \multirow{2}{*}{$\begin{array}{l}\text { Kumamoto (1998)'s Segmented faults } \\
\text { MTL_Akaishi_nishi }\end{array}$} & \multicolumn{4}{|c|}{$\operatorname{Lf}(\mathbf{k m}) \operatorname{Lr}(\mathbf{k m})$ Ratio } \\
\hline & & $\mathbf{a}$ & 54 & 24 & 0.44 & & & e & 52 & 23 & 0.44 \\
\hline 2 & & b & 54 & 32 & 0.59 & 28 & Neodani & a & 67 & 18 & 0.27 \\
\hline 3 & Sekiya & a & 40 & 22 & 0.55 & 29 & & b & 67 & 18 & 0.27 \\
\hline 4 & & b & 40 & 18 & 0.45 & 30 & & c & 67 & 17 & 0.25 \\
\hline 5 & Fukaya" & a & 50 & 30 & 0.60 & 31 & & d & 67 & 19 & 0.28 \\
\hline 6 & & $b$ & 50 & 20 & 0.40 & 32 & & e & 67 & 16 & 0.24 \\
\hline 7 & Shinanogawa & a & 60 & 15 & 0.25 & 33 & & $f$ & 67 & 15 & 0.22 \\
\hline 8 & & $b$ & 60 & 16 & 0.27 & 34 & Yanagase & a & 56 & 21 & 0.38 \\
\hline 9 & & c & 60 & 16 & 0.27 & 35 & & b & 56 & 18 & 0.32 \\
\hline 10 & & d & 60 & 29 & 0.48 & 36 & & c & 56 & 18 & 0.32 \\
\hline 11 & Itoshizusen_chubu & a & 112 & 23 & 0.21 & 37 & Hanaore & a & 54 & 25 & 0.46 \\
\hline 12 & & b & 112 & 27 & 0.24 & 38 & & b & 54 & 22 & 0.41 \\
\hline 13 & & c & 112 & 23 & 0.21 & 39 & & c & 54 & 12 & 0.22 \\
\hline 14 & & d & 112 & 20 & 0.18 & 40 & Arima_Takatsuki & a & 53 & 26 & 0.49 \\
\hline 15 & & e & 112 & 26 & 0.23 & 41 & & b & 53 & 24 & 0.45 \\
\hline$\overline{16}$ & Atotsugawa & a & 61 & 18 & 0.30 & 42 & Rokko-Awaji & a & 62 & 18 & 0.29 \\
\hline 17 & & b & 61 & 18 & 0.30 & 43 & & b & 62 & 28 & 0.45 \\
\hline 18 & & c & 61 & 27 & 0.44 & 44 & & c & 62 & 13 & 0.21 \\
\hline 19 & Atera & a & 62 & 19 & 0.31 & 45 & Uemachi ${ }^{3)}$ & a & 43 & 11 & 0.26 \\
\hline 20 & & b & 62 & 20 & 0.32 & 46 & & b & 43 & 18 & 0.42 \\
\hline 21 & . & c & 62 & 18 & 0.29 & 47 & & c & 43 & 14 & 0.33 \\
\hline 22 & & d & 62 & 17 & 0.27 & 48 & Yamasaki & $\mathbf{a}$ & 55 & 28 & 0.51 \\
\hline 23 & MTL_Akaishi_nishi & $\mathbf{a}$ & 52 & 23 & 0.44 & 49 & & b & 55 & 12 & 0.22 \\
\hline 24 & & b & 52 & 23 & 0.44 & 50 & & $\mathrm{c}$ & 55 & 18 & 0.33 \\
\hline 25 & & c & 52 & 26 & 0.50 & 51 & & d & 55 & 19 & 0.35 \\
\hline 26 & & d & 52 & 28 & 0.54 & 52 & & e & 55 & 11 & 0.20 \\
\hline
\end{tabular}

Segmented faults of Kumamoto (1998) are shown except for 1), 2) and 3). For 1) and 3), new segmented faults are identified in this study. For 2), segments a and b are taken from Kumamoto (1998) and segment $c$ is identified on the basis of Matsuda (1995). The length of Matsuda model fault is shown by $L f$, and the length of Kumamoto model fault by $L r$. The ratio of $L r$ to $L f$ is shown in the last column. 
(a)

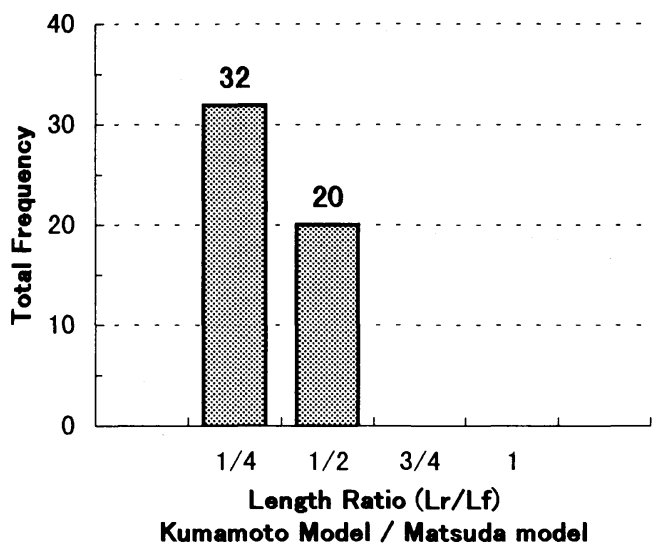

(b)

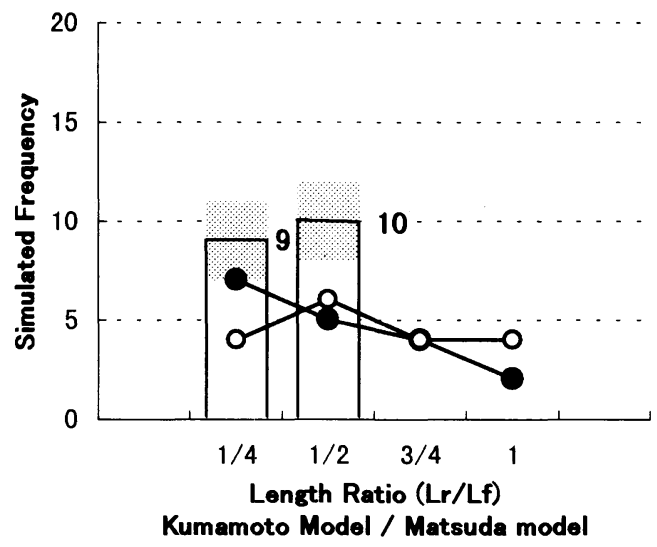

Fig. 3. Histogram of ratios of the length of Kumamoto model to that of Matsuda model listed in Table 2. (a): all segments, (b): simulation results. In (b), the shaded area indicates $95 \%$ confidence interval. The closed circle illustrates the observed frequency for all the data shown in Fig. 2(b). The open circle shows the relative frequency for the data with reliability ranks a and b in Fig. 2(b).

として, 隈元 (1998) の断層セグメントに加えた (Table $3)$.

松田 (1990) の起震断首の 1 つである跡津川断層帯を 例にすると (Fig. 4), 隈元 (1998) は, 松田 (1990) の跡津 川断層帯を 3 つの断層セグメントに分割している. 便宜 上一方の端から順に個々の断首セグメントを $\mathrm{a}, \mathrm{b}, \mathrm{c}$ と呼 ぶと，隣接するセグメントの組合せは $\mathrm{a}+\mathrm{b}+\mathrm{c}, \mathrm{a}+\mathrm{b}$, $\mathrm{b}+\mathrm{c}$ となる。このうち, 組合せ $\mathrm{a}+\mathrm{b}+\mathrm{c}$ は松田 (1990) の起震断層に相当する．この隣接する断層セグメントの 組合せを隈元モデル a, b, c に加えるので, 最終的に, $\mathrm{a}+\mathrm{b}+\mathrm{c}, \mathrm{a}+\mathrm{b}, \mathrm{b}+\mathrm{c}, \mathrm{a}, \mathrm{b}, \mathrm{c}$ の全ての区間が， 1 つの大地 震における活動単位として設定される。本研究では, こ のような断層設定を連動セグメントモデルと呼ぶことに する.

連動セグメントモデルを用いて 4.1 のシミュレーショ ンを行い，その結果をFig. 5 に示した. Fig. 5(a) は連動 セグメントがすべて 1 回ずつ活動した場合の地震発生 頻度, Fig. 5(b) はシミュレーション結果である. Fig. 5 (b) より, 割合が $3 / 4$ の地震の発生頻度がやや小さいむ のの，95\%の信頼区間で見れば，連動セグメントモデル を用いたシミュレーション結果は歴史地震デー夕調査結 果と非常によく対応している. 本研究のシミュレーショ ンでは, 大地震が発生しうる断層セグメント（連動セグ メントむ含む）は，すべて均しい確率で活動すると想定 されているが，現実には，1つの起震断首に属するすべ ての断層セグメントが同時に活動する確率より, 起震断 層全体の長さよりやや短い連動セグメントが活動する確 率が高い可能性がある.

\section{§5. 日本陸域活断層で発生する大地震の規模の特徵}

全ての地震データを用いて地震の規模と発生頻度の関 係を求めると, 大きな地震ほど少なく, 小さな地震ほど 多く発生するというグーテンベルグ・リヒターの式（以 下 G-R 式と呼ぶ）で表される統計学的傾向をむつこと が知られている．1つの活断層系（ここでは，ある一定 の地域において, 最大規模の地震でまとまって動く活断 層群あるいは区間という意味で用いる）で起こる地震に ついても, 固有地震モデル $[1$ つの活断層系では, 規模 とある点（あるいは区間）における 1 回のずれ量がいつ あ同一である固有な大地震が繰り返し発生するというモ デル] が提唱 [SCHWARZ and Coppersmith (1984)]され る以前は，G-R 式に従うと考えられていた。しかし，地 形・地質学的証拠に加えて，1つの活断層系で生じた地 震デー夕のみを用いて規模と発生頻度の関係を見た場 合, 最大規模の地震はいつも同程度の大きさで発生し, それよりやや小さな地震は発生せず, 地震マグニチュー ドと累積地震数 (対数) の分布は, 最大余震より小さな マグニチュードの範囲では直線となり G-R 式に従うが, 本震である最大規模の地震は余震デー夕によって決定さ れる G-R 式の直線から外れる, という結果になり, 固有 地震モデル説が優勢となった [STIRLING et al. (1996)].

しかし, 本研究の歴史地震デー夕調查結果は, 1 つの 活断層系で起こる大地震 (本震) の規模はつねに一定で はないことを示している，それでは，日本列島の陸域に おける 1 つの活断層系で発生する大地震 (本震) は, 規 模の固有性がなく, 1 回の地震ごとに規模は様々に变化 するのだろうか.ここではこの問題を中心に議論し，日 
Table 3. Proposed fault model in this study.

\begin{tabular}{|c|c|c|c|c|c|c|c|c|c|c|c|}
\hline No. & Proposed Model Faults & & $\mathrm{Lf}(\mathrm{km}$ & $\operatorname{Lr}(\mathrm{km}$ & Ratio & No. & Proposed Model Faults & & $\mathrm{Lf}(\mathrm{km}$ & $r(\mathrm{~km}$ & Ratio \\
\hline 1 & Yokote_bonchi toen & $\overline{a b}$ & 54 & 54 & 1.00 & 46 & Neodani & abcdef & 67 & 67 & 1.00 \\
\hline 2 & & a & 54 & 24 & 0.44 & 47 & & $a b c d$ & 67 & 58 & 0.87 \\
\hline 3 & & b & 54 & 32 & 0.59 & 48 & & cdef & 67 & 55 & 0.82 \\
\hline 4 & Sekiya & $a b$ & 40 & 40 & 1.00 & 49 & & cde & 67 & 39 & 0.58 \\
\hline 5 & & a & 40 & 22 & 0.55 & 50 & & def & 67 & 37 & 0.55 \\
\hline 6 & & b & 40 & 18 & 0.45 & 51 & & $a b$ & 67 & 36 & 0.54 \\
\hline 7 & Fukaya & $a b$ & 50 & 50 & 1.00 & 52 & & $\mathrm{~cd}$ & 67 & 36 & 0.54 \\
\hline 8 & & a & 50 & 30 & 0.60 & 53 & & de & 67 & 35 & 0.52 \\
\hline 9 & & b & 50 & 20 & 0.40 & 54 & & ef & 67 & 31 & 0.46 \\
\hline 10 & Shinanogawa & abcd & 60 & 60 & 1.00 & 55 & & a & 67 & 18 & 0.27 \\
\hline 11 & & $a b c$ & 60 & 47 & 0.78 & 56 & & b & 67 & 18 & 0.27 \\
\hline 12 & & bcd & 60 & 52 & 0.87 & 57 & & c & 67 & 17 & 0.25 \\
\hline 13 & & $a b$ & 60 & 31 & 0.52 & 58 & & d & 67 & 19 & 0.28 \\
\hline 14 & & bc & 60 & 32 & 0.53 & 59 & & e & 67 & 16 & 0.24 \\
\hline 15 & & $\mathrm{~cd}$ & 60 & 36 & 0.60 & 60 & & $f$ & 67 & 15 & 0.22 \\
\hline 16 & & a & 60 & 15 & 0.25 & 61 & Yanagase & $a b c$ & 56 & 56 & 1.00 \\
\hline 17 & & b & 60 & 16 & 0.27 & 62 & & $a b$ & 56 & 39 & 0.70 \\
\hline 18 & & c & 60 & 16 & 0.27 & 63 & & bc & 56 & 36 & 0.64 \\
\hline 19 & & d & 60 & 20 & 0.33 & 64 & & a & 56 & 21 & 0.38 \\
\hline 20 & Itoshizusen_chubu & abcde & 112 & -112 & 1.00 & 65 & & b & 56 & 18 & 0.32 \\
\hline 21 & & cde & 112 & 69 & 0.62 & 66 & & c & 56 & 18 & 0.32 \\
\hline 22 & & $a b$ & 112 & 50 & 0.45 & 67 & Hanaore & $a b c$ & 54 & 54 & 1.00 \\
\hline 23 & & $c d$ & 112 & 43 & 0.38 & 68 & & $a b$ & 54 & 47 & 0.87 \\
\hline 24 & & de & 112 & 46 & 0.41 & 69 & & a & 54 & 25 & 0.46 \\
\hline 25 & & a & 112 & 23 & 0.21 & 70 & & b & 54 & 22 & 0.41 \\
\hline 26 & & b & 112 & 27 & 0.24 & 71 & & c & 54 & 12 & 0.22 \\
\hline 27 & & c & 112 & 23 & 0.21 & 72 & Arima_Takatsuki & $a b$ & 53 & 53 & 1.00 \\
\hline 28 & & d & 112 & 20 & 0.18 & 73 & & a & 53 & 26 & 0.49 \\
\hline 29 & & e & 112 & 26 & 0.23 & 74 & & b & 53 & 24 & 0.45 \\
\hline 30 & Atotsugawa & $a b c$ & 61 & 61 & 1.00 & 75 & Rokko-Awaji & $a b c$ & 62 & 62 & 1.00 \\
\hline 31 & & $a b$ & 61 & 36 & 0.59 & 76 & & $a b$ & 62 & 47 & 0.76 \\
\hline 32 & & bc & 61 & 45 & 0.74 & 77 & & a & 62 & 18 & 0.29 \\
\hline 33 & & a & 61 & 18 & 0.30 & 78 & & b & 62 & 28 & 0.45 \\
\hline 34 & & b & 61 & 18 & 0.30 & 79 & & c & 62 & 13 & 0.21 \\
\hline 35 & & c & 61 & 27 & 0.44 & 80 & Uemachi & $a b c$ & 43 & 43 & 1.00 \\
\hline 36 & Atera & $a b c d$ & 62 & 62 & 1.00 & 81 & & $a b$ & 43 & 29 & 0.67 \\
\hline 37 & & $a b$ & 62 & 39 & 0.63 & 82 & & bc & 43 & 32 & 0.74 \\
\hline 38 & & $\mathrm{~cd}$ & 62 & 35 & 0.56 & 83 & & a & 43 & 11 & 0.26 \\
\hline 39 & & a & 62 & 19 & 0.31 & 84 & & b & 43 & 18 & 0.42 \\
\hline 40 & & b & 62 & 20 & 0.32 & 85 & & c & 43 & 14 & 0.33 \\
\hline 41 & & c & 62 & 18 & 0.29 & 86 & Yamasaki & $a b c$ & 55 & 55 & 1.00 \\
\hline 42 & & d & 62 & 17 & 0.27 & 87 & & $a b$ & 55 & 40 & 0.73 \\
\hline 43 & MTL_Akaishi_nishi & $a b$ & 52 & 52 & 1.00 & 88 & & bc & 55 & 30 & 0.55 \\
\hline 44 & & a & 52 & 26 & 0.50 & 89 & & a & 55 & 28 & 0.51 \\
\hline \multirow[t]{2}{*}{45} & & b & 52 & 28 & 0.54 & 90 & & b & 55 & 12 & 0.22 \\
\hline & & & & & & 91 & & c & 55 & 18 & 0.33 \\
\hline
\end{tabular}

A new fault model is proposed by adding faults combining neighboring segments in Table 2, to Kumamoto and Matsuda models. The length of Matsuda model fault is shown by $L f$, and the length of our proposed fault by $L r$. The ratio of $L r$ to $L f$ is shown in the last column.

\section{本列島の陸域活断層で起こる地震の規模の特徴を考察す} る.

前章までは, 地震の規模と発生頻度の関係を, 松田 (1990) の起震断層の長さに対する各断層セグメントの 長さの割合別頻度分布で示した. 一般に地震の規模別発 生頻度分布は, 地震のマグニチュードとそのマグニ チュード以上の総地震数の関係として表される.そこ で, Fig. 2(b), 5(b) について, 横軸の割合 $(L r / L f)$ を地震 のマグニチュードに, 縦軸の地震数を累積地震数の対数 に置き換えた図を作成し, 歴史地震デー夕調查結果と連 動セグメントモデルを用いたシミュレーション結果を比 較することにした。
本来 1 つの活断層系で起こる地震の規模別頻度分布 を考える場合，その活断層系で起きた地震のみを用いる べきであるが, 最大規模の地震の 1 サイクルにわたる長 期間のデータは少ない，そこで, 日本の陸域活断層で発 生する大地震ならば, いずれの活断層系において屯, 発 生する大地震の規模のパターンは同様の性質をあつと仮 定し, 全国の活断層系の規模別地震発生頻度分布を重ね 合わせても，1つの活断層系を解析した場合と同様の特 徵が現れるものと考えた. ただし, 各活断層系の全体の 長さが異なる（つまり最大地震規模が異なる）ため, 絶 対的な大きさとしての地震マグニチュードではなく, 活 断層系全体の長さ [松田 (1990) の起震断層長] で基準化 


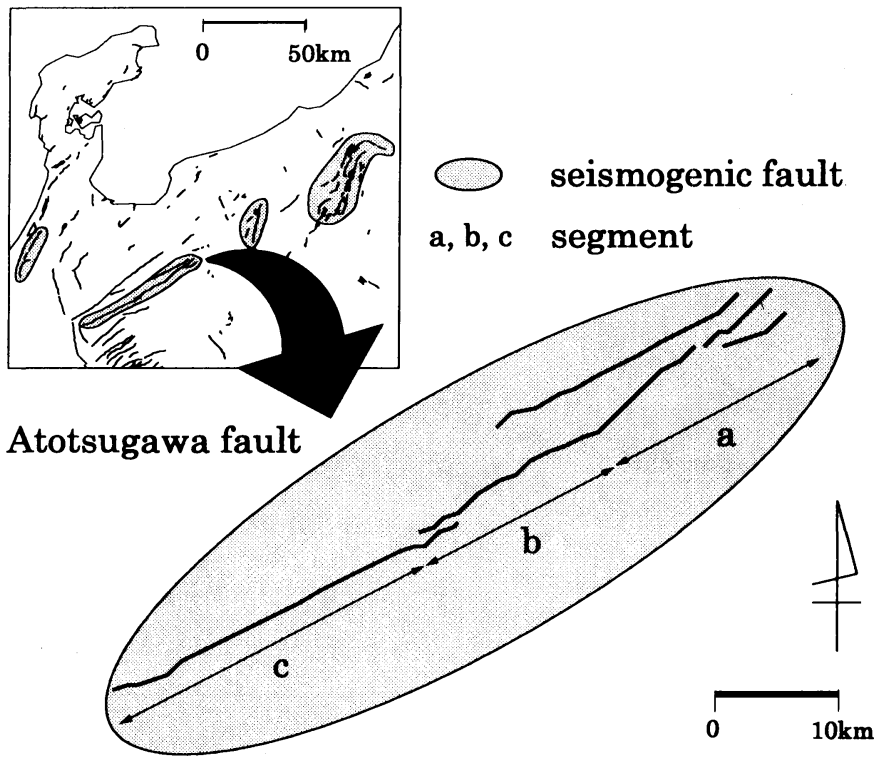

Fig. 4. Example of a "seismogenic fault" and "segmented faults" for the case of the Atotsugawa fault, central Japan. Segments a, b and c are proposed by Кимамото (1998), and the seismogenic fault $\mathrm{a}+\mathrm{b}+\mathrm{c}$ is proposed by Matsuda (1990). Our proposed model includes Matsuda (1990)'s "seismogenic fault" $(\mathrm{a}+\mathrm{b}+\mathrm{c})$, Кимамото (1998)'s "segmented faults" ( $\mathrm{a}, \mathrm{b}$ and $\mathrm{c}$ ) and faults formed by combining neighboring segments $(a+b$ and $b+c)$.

(a)

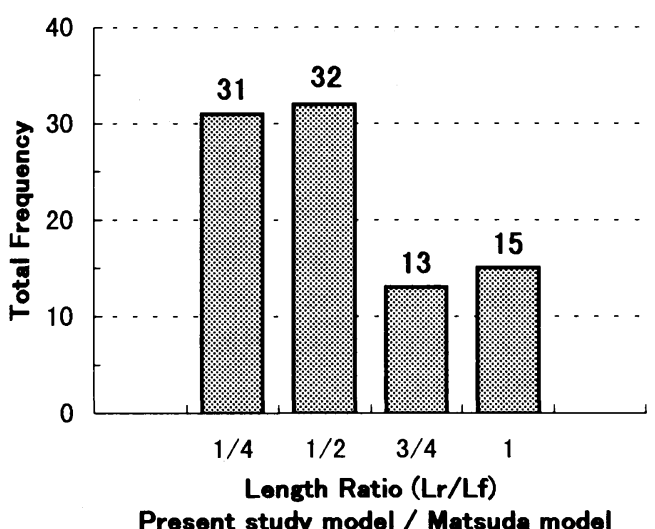

(b)

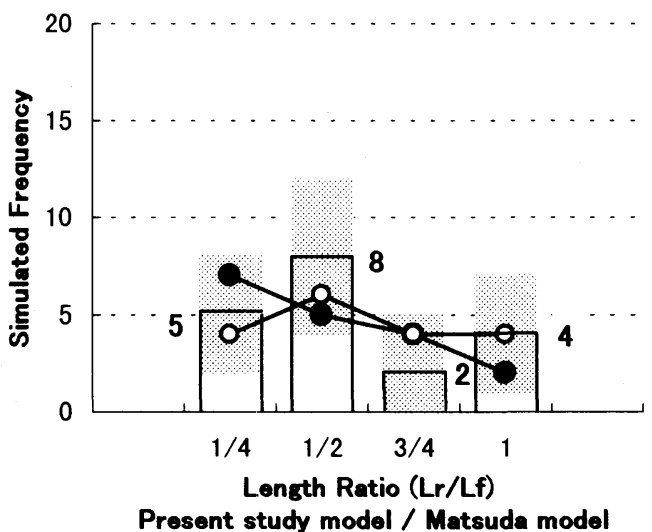

Fig. 5. Histogram of ratios of the length of our proposed model faults to that of Matsuda model faults listed in Table 3. (a) All our proposed model faults, (b) simulation results. In (b) the shaded area indicates $95 \%$ confidence interval. The closed circle illustrates the observed frequency for all the data shown in Fig. 2(b). The open circle shows the relative frequency for all the data with reliability ranks a and $\mathrm{b}$ in Fig. 2(b).

した地震マグニチュード $(\Delta M)$ を用いる．地震のマグニ チュードと断層の長さの関係式 (1) を用いると

$\log (L r / L f)=0.6[M(L r)-M(L f)]$

$$
\equiv 0.6 \Delta M
$$

ここで, $M(L r)$ は地震時に活動した断層の長さから推 定される地震マグニチュードを, $M(L f)$ は起震断層の
長さから推定される地震マグニチュードを表す.

次に地震モーメント $\left(M_{\mathrm{o}}\right)$ と断層パラメー夕の相似則 を用いて, 割合 $(L r / L f)$ から地震マグニチュードへの置 き換えを行う．地震モーメントは断層長の 3 乗に比例す る[KANAMORI and ANDERSON (1975)] という断層パラ メー夕の相似則が成り立つが，日本では，陸域で発生す 


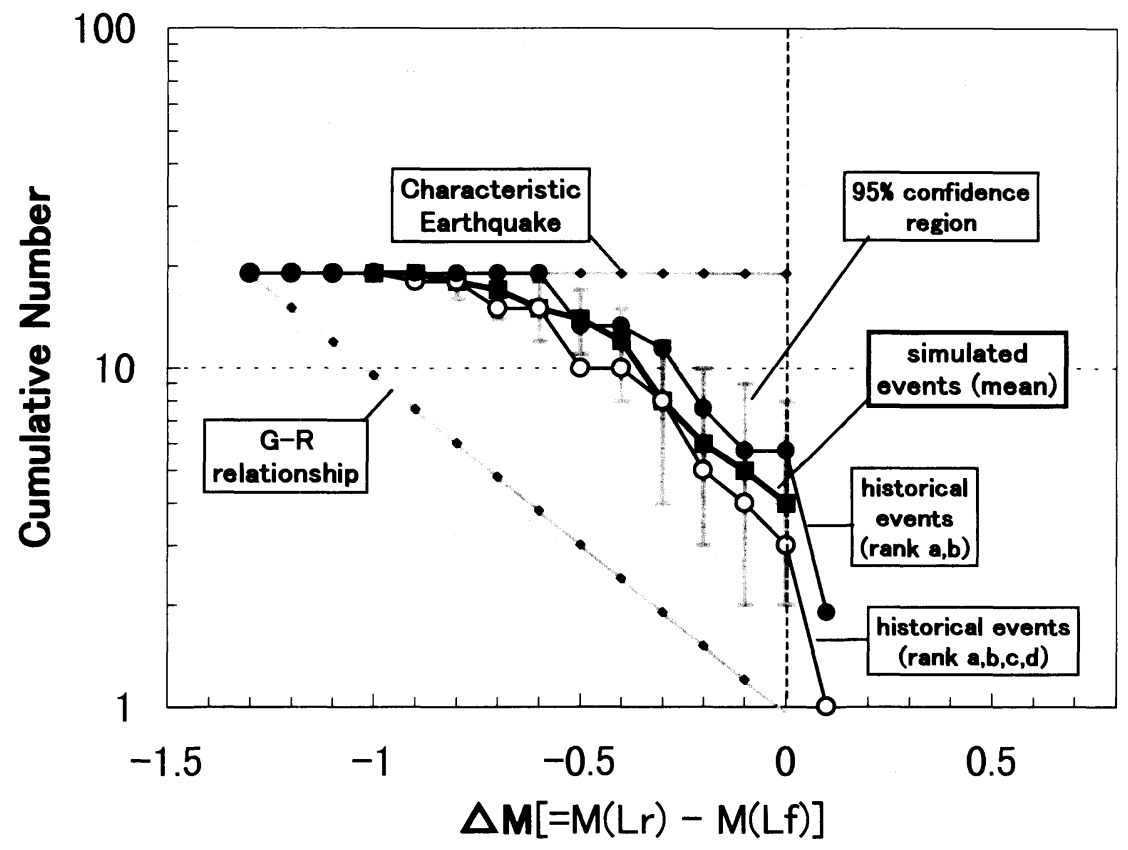

Fig. 6. Cumulative number of simulated and observed events versus relative magnitude. The relative magnitude means a difference in magnitude between a simulated or observed event and a hypothetical earthquake which ruptures all the segments within Matsuda model fault with which the historical event is correlated. The solid square shows a result of simulation for our proposed fault model shown in Table 3 with a bar showing 95\% confidence interval. The closed and open circles show all historical events and events with reliability ranks a and b shown in Fig. 2(b), respectively.

る大地震の場合は, 断層面の幅が地震発生層によって 限られ一定と考えることができる[SHIMAZAKI (1986)]. よって, $M_{\mathrm{o}} \propto L^{2}$ が成り立ち, 地震モーメント (dyne・ $\mathrm{cm})$ と断層の長さ $(\mathrm{km})$ との関係は,

$\log M_{\mathrm{o}}=2 \log L+23.58$

となる [YAMANAKA and SHIMAZAKI (1990)].

一方, 地震モーメントとモーメントマグニチュード $\left(M_{w}\right)$ の関係式[KANAMORI (1977)] は次のとおりであ る.

$\log M_{\mathrm{o}}=1.5 M_{w}+16.1$

(3), (4) 式より $M_{\mathrm{o}}$ を消去して断層の長さ $(L)$ とモーメ ントトマグニチュード $\left(M_{w}\right)$ の関係式を導く.

$M_{w}=1.33 \log L+4.99$

(5) 式から

$\log (L r / L f) \equiv 0.75 M_{w}$

が成り立つ. 前に導いた (2) 式とは，係数が 0.6 と 0.75 で少し異なるが，後述の結論には影響しない，以下では (6) 式を用いる.

Fig. 6 は歴史地震データ調査結果 [Fig. 2(b)] と連動セ グメントモデルのシミュレーション結果が重ねて示され ている. Fig. 6 において, 基準化したマグニチュード 0
は割合 $(L r / L f)$ が 1 ，つまり 1 つの活断層系の全体が一 度に動いた時の地震の大きさを意味する。エラーバーは シミュレーション結果の信頼率 95\%の範囲を示す。ま た, G-R 式に従うモデルと固有地震モデルの場合のグラ フも参考に載せている. Fig. 6 をもとに, 1 つの活断層 系で起こる大地震 (本震) の規模に固有性があるかどう かという問題を考える.

歴史地震デー夕調査結果における地震の大きさと累積 地震数 (対数) の関係は, マグニチュード-0.1〜 - 0.9 の範囲において一定の傾きでほぼ直線として現れ, 固有 地震モデルより G-R 式に従うモデルに適合するように 見える. しかし，マグニチュード $0 \sim-1.0$ 間の $b$ 值を求 めると 0.70 [宇津 (1965) の式による] であり， G-R 式 に従う場合の $b$ 值である 1 とは傾きが異なる.すなわ ち, どちらのモデルとも適合しない.

本研究で扱っている地震はほぼ $M 6.8$ 以上で, 文献・ 資料より余震と考えられている地震は除かれているた め, Fig. 6 は 1 つの活断層系で起こる地震の最大マグ二 チュード付近だけを示していると考えられる. 本震と最 大余震の規模の差は, 一般にマグニチュード 1 以上であ り, 余震む含めて地震の規模と発生頻度の関係を求めれ 
ば，余震分布を表すと考えられるマグニチュードー 1.0 以下のグラフ部分と, 本震の分布と考えられるマグニ チュード 0 付近のグラフの部分では, その傾きが大きく 変化し, 固有地震モデルに類似した, 最大マグニチュー ド付近で直線が前に突出すように折れるグラフになると 考えられる.

また, Fig. 2(b) のグラフにおいても, 割合が 1 の地震 に対して割合が $1 / 2$ や $1 / 4$ の地震の発生頻度はそれほ ど急激に高くならないことから，G-R 式よりあ固有地震 モデルの傾向を示していると考える.

以上より, 本研究結果は, 基本的に 1 つの活断層系で 起こる大地震 (本震) は固有の大きさをむつが, その大 きさにはやや幅があると解釈するのが妥当と考える．ま た, その幅は各活断層系の断層セグメントの構成（数, 組合せなど）に関係すると考えられる.

\section{§6. まとめ}

本研究は, 歴史地震デー夕調查により, 1 つの活断層 系における大地震発生時の活断層の活動パターンを推定 し, シミュレーションにより 1 回の大地震における活動 単位としてより現実的な断層設定を検討した. 結果は以 下のとおりである.

1) 歴史地震デー夕調查により, 松田 (1990) の起震 断層は, 最大規模の地震発生時における活動単位となる 断層 (1つの活断層系) として妥当であり, その場合, 歴 史地震の多くは, 1 つの活断層系全体の長さに対する地 震時に動いた断層の長さの割合が $1 / 4 \sim 1$ の範囲に分布 し, 1 つの活断層系は, 全体が 1 度に動く場合と部分的 に動く場合の両方が考えられる.

2) 1 つの大地震の活動単位となる断層設定として, これまで松田モデル [松田(1990)], 隈元モデル [隈元 (1998)] が提案されたが, これらでは歴史地震デー夕調 查結果を十分に説明できない. 松田 (1990) の起震断層, 隈元 (1998) の個々の断層セグメントとともに，隣接す る断層セグメント [隈元 (1998) による] の組合せを考慮 した断層設定である連動セグメントモデルが歴史地震 デー夕調查結果を最むよく説明できる.

3) 1 つの活断層系において発生する大地震の規模は 固有性をむつが，常に同じマグニチュードではなく，地 震ごとに活動する断層の長さが活断層系全体の長さに対 して 1/4 1 の範囲で変化するため, 大きさには幅があ る. その幅については, 1 つの活断層系に属する断層セ グメントの数や連続性等が関係していると考えられる.

\section{§7. おわりに}

現段階で可能な限り多くの歴史地震と活断層を対応付
けたが, 対応付けられた地震数は 36 と少なく, その中 には確実性の低いむのも含まれる.今後さらに活断層に 関する調查を進め, より多く確実に歴史地震と活断層を 対応付けることが重要である.

また, 当面強震動予測を試みる場合には, 1 回の大地 震で活動する断層の長さが, 松田 (1990) の起震断層長 の $1 / 4 \sim 1$ の範囲に分布することを考慮すべきであろ う. 論理ツリー [地震調查研究推進本部地震調査委員会 長期評価部会 (1999)] などの手法によって, その不確定 性を組み入れるここが考えられる.

\section{謝辞}

本研究は, 小田切が「国立試験研究機関等に従事する 研究職員のための国内留学制度」に基づき，科学技術庁 より東京大学地震研究所に 10 ヶ月間派遣され, 実施し たものである. その際，科学技術庁科学技術振興局およ び地震研究所の方々には大変お世話になった. また, 査 読者の松田時彦氏, 遠田晋次氏, および編集者の堤 浩 之氏には丁寧に読んで頂き, 有益なコメントは本論文の 改善に非常に役立った.これらの方々に深く感謝する.

\section{文献}

Arrowsmith, R., K. Mcnally and J. Davis, 1997, Potential for earthquake rupture and $M 7$ earthquakes along the Parkfield, Cholame, and Carrizo segments of the San Andreas Fault, Seism. Res. Lett., 68, 902-916.

Hashimoto, M., T. Sagiya, H. Tsuji, Y. Hatanaka and T. TAdA, 1995, Co-seismic Displacement of the 1995 Hyogo-ken Nanbu Earthquake, J. Phys. Earth, 44, 255-279.

地震調查研究推進本部地震調查委員会長期評価部会, 1999, (改訂試案) 長期的な地震発生確率の評価手法 について, $74 \mathrm{pp}$.

KANAMORI, H., 1977, The energy release in great earthquakes, J. Geophys. Res., 82, 2981-2987.

Kanamori, H. and D. L. Anderson, 1975, Theoretical basis of some empirical relations in seismology, Bull. Seism. Soc. Am., 65, 1073-1095.

活断層研究会, 1980, 日本の活断層一分布図之資料一, 東京大学出版会, $363 \mathrm{pp}$.

活断層研究会, 1991, [新編] 日本の活断層一分布図之 資料一, 東京大学出版会, $437 \mathrm{pp}$.

小山真人, 1999 , 日本の史料地震学研究の問題点之展望 一次世代の地震史研究に向けて一, 地学雑誌, 108, 346-369.

隈元 崇, 1998, 活断層のトレンチ調査結果を用いて推 定した日本の内陸地震の長期危険度評価, 地震 2,50 , 別冊, 53-71.

松田時彦, 1975 , 活断層から発生する地震の規模と周期 について, 地震 2, 28, 269-283. 
松田時彦，1990, 最大地震規模による日本列島の地震分 帯図, 地震研究所彙報, 65, 289-319.

松田時彦， 1995，1995 年兵庫県南部地震はどこまで予 測されていたか, 月刊地球号外，13，90-94.

松田時彦・由井将雄・松島義章・今永 勇 - 平田大二・ 東郷正美・鹿島 薰・松原彰子・中井信之・中村俊 夫・松岡数充, 1988, 伊勢原断層 (神奈川県) の試錐 による地下調查一過去約 7000 年間の堆積環境之元慶 2 年地震の変位一, 地震研究所彙報, 63, 145-182.

Matsu'Ura, M., 1977, Inversion of geodetic data, Part II, Optimal model of conjugate fault system for the 1927 Tango earthquake, J. Phys. Earth, 25, 233255.

小田切聡子 - 島崎邦彦, 2000 , 歴史地震と起震断層との 対応 (投稿中).

佐竹健治・石田瑞穂・杉山雄一, 1997, 地震構造図, 50 万分の 1 活構造図「東京」(第 2 版) 説明書, 地質調查 所, 9-12.

佐藤良輔 - 阿部勝征 - 岡田義光 - 島崎邦彦・鈴木保典, 1989, 日本の地震断層パラメター・ハンドブック, 鹿 島出版会, $390 \mathrm{pp}$.

Schwartz, D. P. and K. J. Coppersmith, 1984, Fault behavior and characteristic earthquakes: Examples from the Wasatch and San Andreas fault zones, J. Geophys. Res., 89, 5681--5698.

SHImAZAKI, K., 1986, Small and large earthquakes: the effects of the thickness of seismogenic layer and the free surface, in "Earthquake Source Mechanics", ed. by S. Das, J. Boatwright and C. Scholz, AGU
Geophys. Monograph, 37, AGU, Washington D. C., 209-216.

Sieh, K., M. Stuiver and D. Brillinger, 1989, A more precise chronology of earthquakes produced by the San Andreas Fault in southern California, J. Geophys. Res., 94, 603-623.

Stirling, M. W., S. G. Wesnousky and K. Shimazaki, 1996, Fault trace complexity, cumulative slip, and the shape of the magnitude-frequency distribution for strike-slip faults: a global survey, Geophys. J. Int., 124, 833-868.

杉山雄一, 1997. 上町断層系の反射法地震探査, 地質調 查所研究資料集, 303 (平成 8 年度活断層研究調查概 要報告書), 105-113.

武村雅之, 1998, 日本列島における地款内地震のスケー リング則, 地震 2, 51, 211-228.

宇佐美龍夫, 1996, 新編日本被害地震総覧 [増補改訂版 416-1995], 東京大学出版会, $493 \mathrm{pp}$.

宇津徳治, 1965, 地震の規模別度数の統計式 $\log \mathrm{n}=\mathrm{a}-$ $\mathrm{bM}$ の係数 b を求める一方法, 北海道大学地球物理研 究報告, 13, 99-103.

Working Group on California Earthquake ProBABILITIES, 1995, Seismic hazards in southern California: probable earthquakes, 1994 to 2024, Bull. Seism. Soc. Am., 85, 379-439.

YAmanaKa, Y. and K. ShimazaKi, 1990, Scaling relationship between the number of aftershocks and the size of the main shock, J. Phys. Earth, 38, 305-324. 